\title{
Karakterisasi Reservoar Hidrokarbon Menggunakan Atribut Energi dan Metode Seismic Coloured Inversion (SCI) Pada Lapangan Penobscot Kanada
}

\author{
Jarnal Witarsa ", Dwi Pujiastuti, Elistia Liza Namigo \\ Laboratorium Fisika Bumi, Jurusan Fisika \\ Fakultas Matematika dan Ilmu Pengetahuan Alam Universitas Andalas \\ Kampus Unand Limau Manis, Padang, 25163 Indonesia \\ *Jarnal08witarsa@gmail.com
}

\begin{abstract}
ABSTRAK
Telah dilakukan karakterisasi reservoar hidrokarbon pada Lapangan Penobscot Kanada menggunakan atribut energi dan metode Seismic Coloured Inversion (SCI) di sepanjang inline $1284 \mathrm{~m}$. Penelitian ini menggunakan data seismik post stack sebagai data input dan data sumur sebagai data kontrol untuk menentukan nilai impedansi akustik $(A I)$. Analisis sensitivitas log yang digunakan menunjukkan bahwa gamma ray log lebih sensitif dalam pemisahan lapisan sand dan shale. Analisis atribut energi dilakukan untuk meningkatkan resolusi vertikal dari penampang seismik untuk menentukan zone of interest. Analisis inversi SCI dilakukan untuk melihat pola sebaran nilai $A I$ pada penampang seismik yang diteliti. Dari hasil inversi $S C I$ terhadap penampang seismik diperoleh nilai $A I$ antara $2,00 \times 10^{6} \mathrm{~kg} / \mathrm{m}^{2} \mathrm{~s}$ sampai $5,56 \times 10^{6} \mathrm{~kg} / \mathrm{m}^{2} \mathrm{~s}$. Hal ini menunjukkan bahwa pada penampang seismik yang diteliti terdapat potensi reservoar hidrokarbon.
\end{abstract}

Kata kunci: atribut energi, Seismic Coloured Inversion (SCI), Acoustic Impedance (AI), Zone Of Interest.

ABSTRACT

The characterization of hydrocarbon reservoirs in the Penobscot Field Canada using energy attribute and the Seismic Coloured Inversion (SCI) method along inline 1284. This study uses seismic data as input and well data as control to determine the value of acoustic impedance (AI). The log sensitivity analysis used shows that gamma ray logs are more sensitive in the separation of sand and shale layers. Energy attribute analysis is performed to increase the vertical resolution of the seismic cross section to determine the zone of interest. SCI inversion analysis is performed to see the AI distribution pattern on seismic cross section of the study. From the SCI inversion to the seismic cross section, it was obtained that the AI value is between $2.00 \times 10^{6} \mathrm{~kg} / \mathrm{m}^{2} \mathrm{~s}$ to $5.56 \times 10^{6} \mathrm{~kg} / \mathrm{m}^{2} \mathrm{~s}$. This indicates that there is hydrocarbon content in the seismic cross section of the reservoir in study.

Keywords: energy attribute, Seismic Coloured Inversion (SCI), Acoustic Impedance (AI), Zone Of Interest.

\section{PENDAHULUAN}

Peningkatan kebutuhan energi minyak dan gas harus diimbangi dengan peningkatan usaha eksplorasi dan eksploitasi energi minyak dan gas. Eksplorasi dilakukan untuk mengetahui informasi hidrokarbon pada suatu wilayah melalui informasi atau gambaran bawah permukaan (Gauthier dan Daukoru, 1993).

Serangkaian kegiatan eksplorasi dapat dilakukan dengan beberapa kajian diantaranya kajian geologi, geokimia, dan geofisika (Koesoemadinata, 1980). Metode seismik merupakan bagian dari kajian geofisika yang umum digunakan dalam mengetahui informasi keberadaan hidrokarbon pada suatu daerah. Menurut Badley (1985) metode seismik digunakan untuk melihat kemungkinan adanya hidrokarbon yang terperangkap pada batuan reservoar di bawah permukaan. Informasi litologi bawah permukaan dapat diperoleh melalui pengintegrasian data seismik dan data sumur. Data seismik memiliki kemampuan yang cukup baik dalam penggambaran keadaan litologi bawah permukaan bumi secara lateral, sedangkan data sumur menghasilkan penggambaran bawah permukaan bumi secara vertikal dengan sangat baik (Catra, 2010).

Pengintegrasian data seismik dan data sumur dapat dilakukan menggunakan salah satu metode analisis yaitu penerapan atribut seismik dan metode seismik inversi. Atribut seismik merupakan keseluruhan informasi yang diperoleh dari data seismik baik yang terukur, terhitung, maupun yang tersirat yang digunakan untuk meningkatkan resolusi vertikal pada data seismik dan memperjelas anomali pada data seismik, sedangkan seismik inversi merupakan suatu teknik 
untuk mendapatkan model bawah permukaan bumi dengan data seismik sebagai input dan data sumur sebagai kontrol dengan tampilan impedansi akustik yang lebih interpretatif dalam memetakan keadaan bawah permukaan (Sukmono, 2000). Kelebihan metode seismik inversi adalah memiliki keakuratan dan resolusi vertikal yang cukup tinggi (Arifien, 2010).

Pada metode seismik inversi, penampang seismik dikonversi ke dalam bentuk impedansi akustik yang merepresentasikan sifat fisis batuan sehingga lebih mudah untuk diinterpretasikan menjadi parameter - parameter petrofisik misalnya untuk menentukan litologi batuan dan penyebarannya (Tabah dan Hernowo, 2010). Metode seismik inversi yang digunakan pada penelitian ini adalah metode Seismic Coloured Inversion (SCI). Prinsip metode $S C I$ menganalisis variasi seismik dan spektrum well log untuk membuat operator yang dapat secara langsung mengubah sebuah trace seismik menjadi trace reflektivitas. Menurut Lancaster dan Whitcombe (2000), dibandingkan dengan metode inversi impedansi akustik lainnya seperti metode inversi deterministik, metode $S C I$ ini lebih efisien dari segi waktu dan mudah digunakan. Hasil inversi dengan metode $S C I$ juga lebih andal jika dibandingkan dengan metode lainnya.

Fitri (2016) telah melakukan penelitian di Lapangan F3 Belanda menggunakan metode $S C I$. Dari hasil penelitiannya dapat ditentukan potensi hidrokarbon pada lapisan batuan yang diteliti yaitu berdasarkan metode $S C I$ diperoleh nilai AI yang berkisar antara 4,3 x 10 $-5,3 \times$ $10^{6} \mathrm{~kg} / \mathrm{m}^{2} \mathrm{~s}$ pada dua sumur yang digunakan. Hal ini menunjukkan bahwa pada penampang seismik yang diteliti berkemungkinan adanya potensi hidrokarbon karena nilai AI nya yang rendah. Pada tahun 2011, Peryoga telah melakukan penelitian menggunakan metode Elastic Impedance pada Lapangan Penobscot Kanada. Dari hasil penelitiannya disimpulkan bahwa pada Lapangan Penobscot terdapat zona gas, yaitu berada pada nilai EI $17500 \mathrm{ft} . \mathrm{gr} / \mathrm{s}$ scc sampai dengan $22500 \mathrm{ft} . \mathrm{gr} / \mathrm{s} . \mathrm{cc}$. Hanya saja pada penelitian ini tidak membahas tentang sebaran nilai $A I$ pada Lapangan Penobscot Kanada, untuk itu dilakukan penelitian pada Lapangan Penobscot Kanada dengan metode yang berbeda.

Pada penelitian kali ini dilakukan karakterisasi reservoar menggunakan atribut energy dan metode Seismic Coloured Inversion pada Lapangan Penobscot Kanada. Hasil penelitian berupa crossplot dan struktur geologi lapangan Penobscot dengan analisis atribut seismik dan metode $S C I$ untuk memberikan pola sebaran $A I$ yang dapat memberikan informasi mengenai keberadaan hidrokarbon pada Lapangan yang diteliti (Whitcombe dan Fletcher, 2001).

\section{METODE}

Penelitian ini menggunakan data pada Lapangan Penobscot Kanada yang dapat diakses secara bebas pada http://opendtect.org/index.php/support/free-seismic-surveys. Data terdiri dari data seismik yang telah melalui tahapan processing dan dua data sumur yaitu sumur B-41 dan sumur L-30. Proses karakterisasi data dilakukan menggunakan software opendtect Versi 5.0.

Penelitian ini menggunakan metode Seismic Coloured Inversion dan atribut energy untuk mengkarakterisasi reservoar hidrokarbon. Input data yang digunakan dalam metode inversi impedansi akustik berupa data sumur dan data seismik 3D post-stack. Langkah langkah yang dilakukan dalam penelitian ini diantaranya :

1. Input data

Data yang diinput adalah data seismik dan data sumur dari Lapangan Penobscot Kanada yang telah melalui tahapan prosesing. Pada penelitian ini, reservoar yang dikarakterisasi mengacu kepada salah satu penampang seismik yaitu pada inline 1284. Data log dari dua sumur yang akan digunakan yaitu log sonic (DT), log porositas, log densitas (RHOB), dan $\log$ GR.

2. Well Seismic Tie

Well seismic tie adalah suatu proses pengikatan data sumur (well) terhadap data seismik. Well seismic tie digunakan untuk menempatkan event reflector seismik pada kedalaman yang sebenarnya serta untuk mengkorelasikan informasi geologi yang diperoleh dari data sumur dengan data seismik. Pada well seismic tie, langkah awal yang dilakukan adalah mengekstraksi wavelet. Ekstraksi wavelet dapat dilakukan dengan dua cara, yaitu ekstraksi wavelet secara statistik dengan menggunakan data seismik dan ekstraksi wavelet dengan 
memanfaatkan data sumur yang ada. Wavelet yang digunakan pada penelitian ini adalah wavelet statistik, yaitu dengan mengekstraksi wavelet cube data seismik di sekitar zona target. Wavelet tersebut digunakan sebagai masukan dalam membuat seismogram sintetik untuk melakukan well seismic tie.

3. Analisis Crossplot

Crossplot dilakukan untuk menganalisa hubungan antara data seismik dan data sumur. Kedua tipe data ini yang dianalisa adalah atribut seismik vs atribut seismik. Analisis crossplot antara beberapa parameter fisis dari reservoar dilakukan untuk melihat karakternya, seperti densitas-sonik, porositas-AI pada pemodelan sumur, kemudian melakukan zonasi untuk membedakan litologi (pasir-lempung) dan membedakan fluida (rine-gas).

4. Analisis Atribut Seismik

Atribut seismik adalah semua informasi yang diperoleh dari data seismik baik yang diukur, dihitung, atau yang tersirat. Dua alasan menggunakan atribut seismik adalah visualisasi (kualitatif) dan integrasi data (kuantitatif). Pada alasan visualisasi berarti menghilangkan informasi yang tidak berguna dari pola yang tidak dapat dilihat pada data original, sedangkan alasan integrasi data (kuantitatif) berarti untuk memperoleh informasi dari sumber yang berbeda yang bisa diintegrasikan oleh metode statistik.

5. Proses Inversi $S C I$

Pada software Opendect, tujuan dari SCI adalah mendesain sebuah operator pada zona target. Beberapa cara kerja dari metode $S C I$ yaitu menginput data seismik serta data sumur B-41 dan L-30, membuat amplitudo terhadap frekuensi dari data seismik kemudian melakukan smoothing pada data seismik. Setelah itu membuat amplitudo terhadap frekuensi dari data sumur dan menentukan trend umum dari plot data sumur. Setelah tahap ini baru operator bisa dibuat dan diterapkan pada penampang seismik. Penampang seismik yang dihasilkan berupa pola sebaran AI yang memberikan informasi mengenai nilai AI dari daerah yan diteliti. Pola sebaran AI yang menghasilkan nilai AI yang besar menandakan bahwa sebuah batuan sulit untuk menghasilkan potensi hidrokarbon karena semakin besar nilai AI maka sebuah batuan akan sulit untuk dilalui oleh aliran fluida.

\section{HASIL DAN DISKUSI}

\subsection{Analisis Well Seismic Tie}

Data sumur yang digunakan pada proses well seismic tie adalah data sumur L-30 dan data sumur B-41 berdasarkan ketersediaan pada data. Gambar 1 merupakan proses well seismic tie pada sumur B-41.

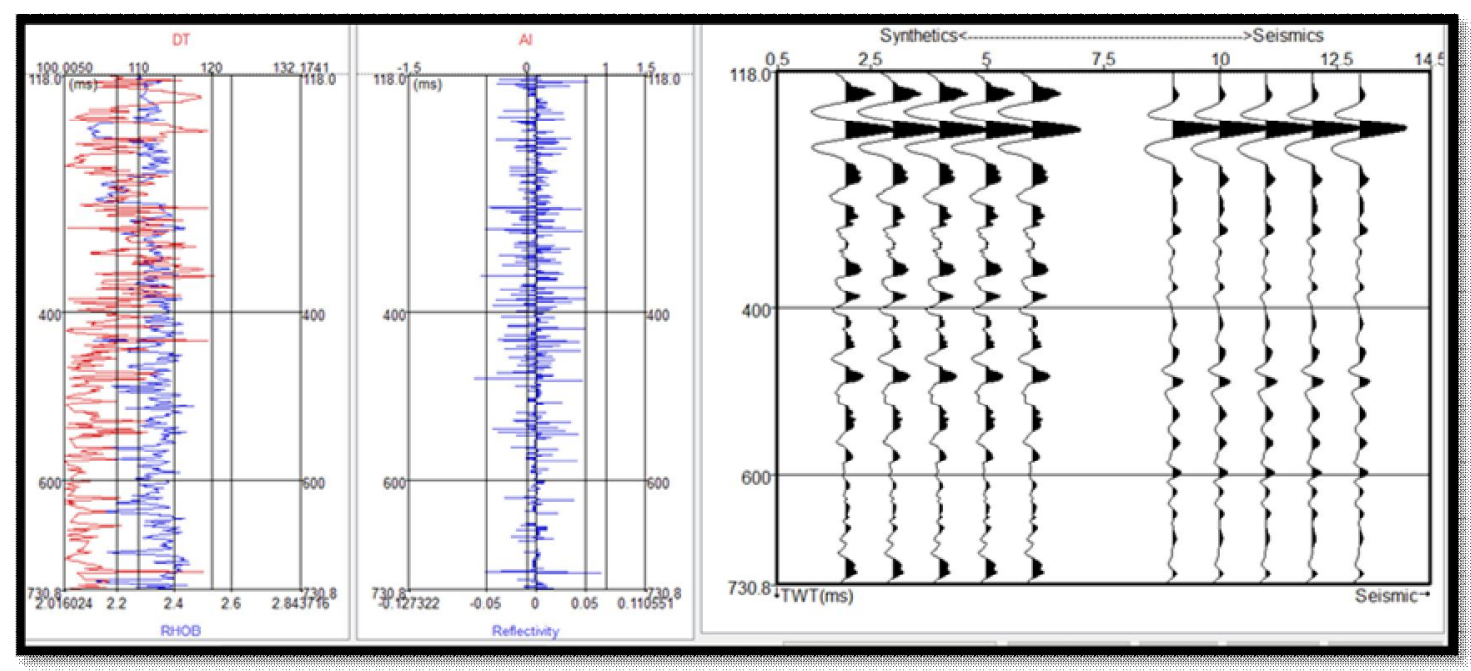

Gambar 1 Proses Well Seismic Tie Pada Sumur B-41 
Proses well seismic tie dikatakan memiliki hasil yang sangat baik apabila nilai koefisien korelasi yang didapatkan mendekati nilai literaturnya yaitu satu. Gambar 2 merupakan nilai koefisien korelasi dari sumur B-41 dengan nilai 0.554. Nilai ini sudah bisa dikategorikan baik untuk melihat kecocokan antara data seismik dan data sumur.

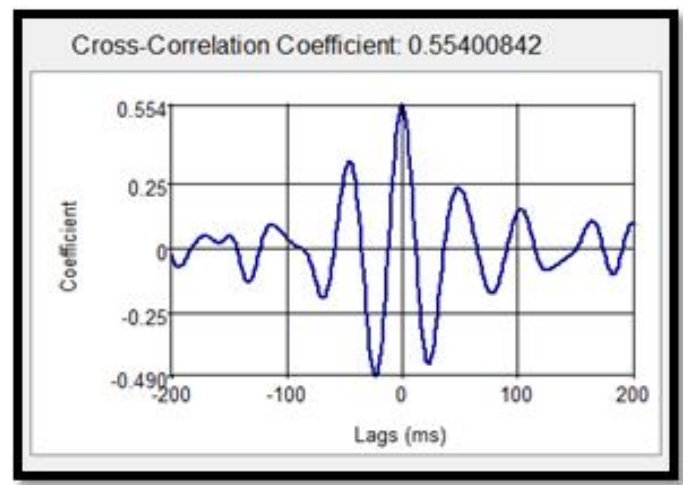

Gambar 2 Koefisien Korelasi Sumur B-41

Gambar 3 merupakan hasil well seismic tie dari sumur L-30. Hasil well seismic tie pada sumur L-30 memiliki nilai koefisien korelasi sebesar 0.606 seperti yang terlihat pada Gambar 4. Hal ini menunjukkan bahwa pada sumur L-30 terjadi pengikatan yang lebih baik dari pada sumur B-41 karena nilai koefisien korelasi pada sumur L-30 lebih besar dibandingkan nilai koefisien korelasi pada sumur B-41.

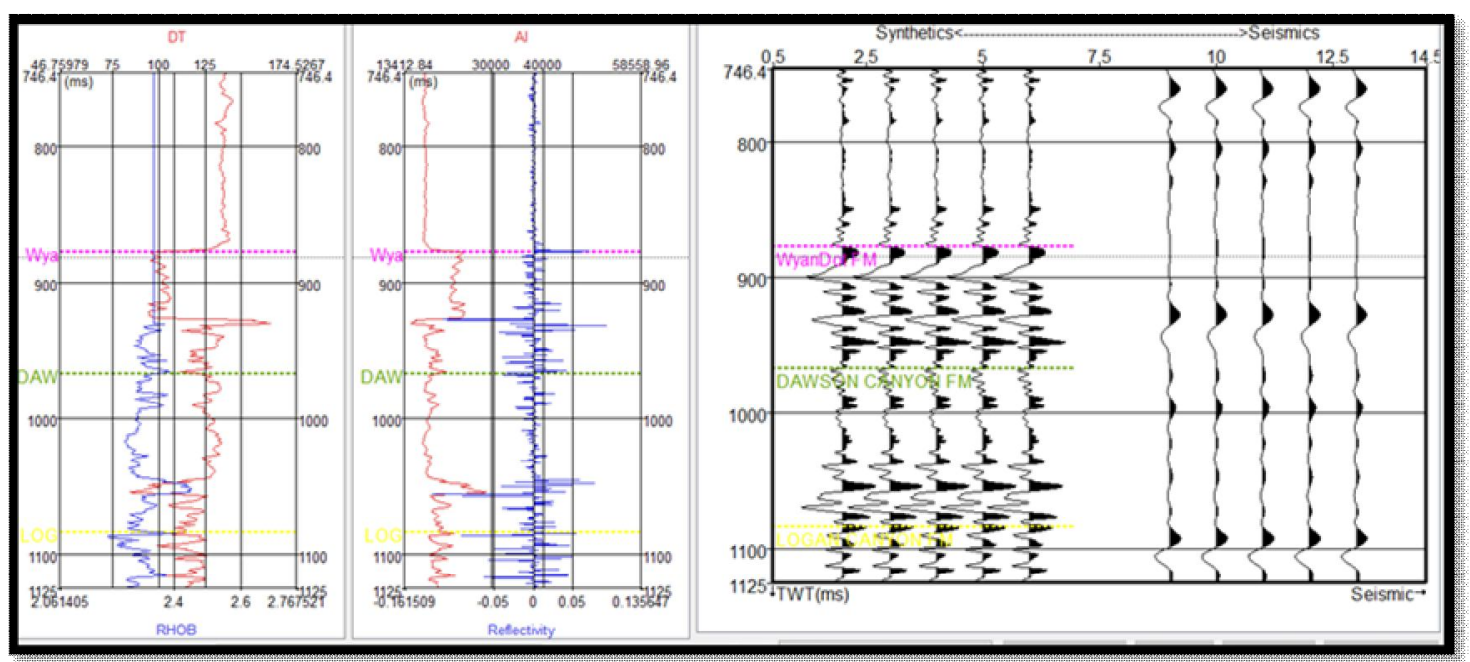

Gambar 3 Proses Well Seismic Tie Pada Sumur L-30

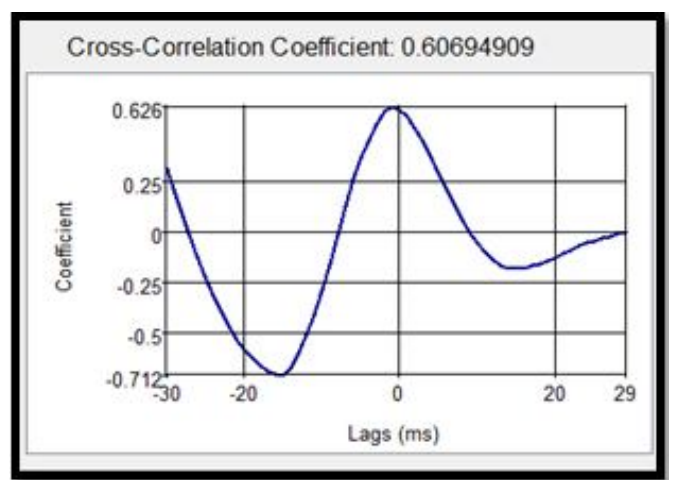

Gambar 4 Koefisien Korelasi Sumur L-30 


\subsection{Analisis Crossplot}

Dari hasil crossplot antara log AI dan log Gamma Ray (Gambar 5), dapat dilihat bahwa Gamma Ray lebih sensitif dari pada log lainnya dalam pemisahan shale dan sand, hal ini dapat dilihat dari sebaran titik pada hasil crossplot. Sebaran titik dari hasil crossplot antara Gamma Ray dan AI lebih jelas dan merata jika dibandingkan dengan hasil crossplot data log lainnya. Gambar 3 menunjukkan bahwa kotak warna biru merupakan lapisan sandstone dengan nilai Gamma Ray yang lebih kecil dibandingkan shale (kotak warna hijau) berkisar antara 20 API sampai 75 API dan nilai $A I$ antara $2,8 \times 10^{6} \mathrm{~kg} / \mathrm{m}^{2}$ s sampai $5,9 \times 10^{6} \mathrm{~kg} / \mathrm{m}^{2} \mathrm{~s}$, sedangkan kotak warna hijau merupakan lapisan shale yang memiliki nilai Gamma Ray antara 75 API sampai 120 API dan nilai $A I$ berkisar antara $1,3 \times 10^{6} \mathrm{~kg} / \mathrm{m}^{2} \mathrm{~s}$ sampai $4,0 \times 10^{6} \mathrm{~kg} / \mathrm{m}^{2} \mathrm{~s}$.

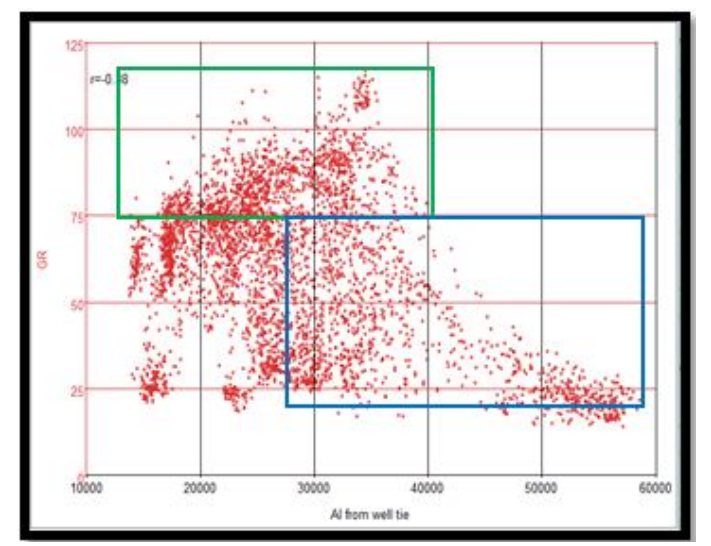

Gambar 5 Crossplot antara $\log$ AI dan log Gamma Ray Pada Sumur L-30

\subsection{Analisis Atribut Energi}

Pada penelitian ini telah dilakukan analisis terhadap penampang seismik dengan inline 1284 menggunakan software OpendTect. Gambar 6 (a) merupakan interpretasi dari penampang seismik pada inline 1284 dimana resolusi vertikalnya masih rendah sehingga keberadaan reservoar hirdokarbon sulit untuk diketahui. Resolusi vertikal yang tinggi pada penampang seismik akan memudahkan untuk mendeteksi keberadaan reservoar hidrokaron. Untuk itu dilakukan ekstraksi atribut energi dengan data seismik post-stack dan data sumur sebagai pengontrolnya. Dalam interpretasi atribut energi ini dilakukan analisis dengan time gate -28 sampai +28 dengan inline yang sama seperti Gambar 6 (a) yaitu inline 1284 dan compute gradient nya tidak diaktifkan.

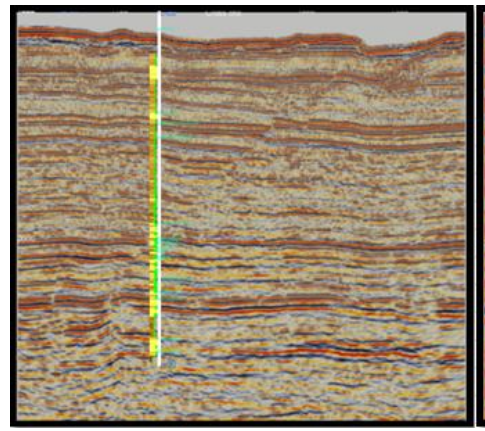

(a)

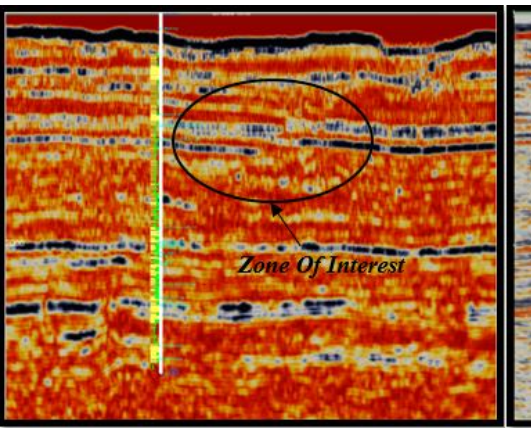

(b)

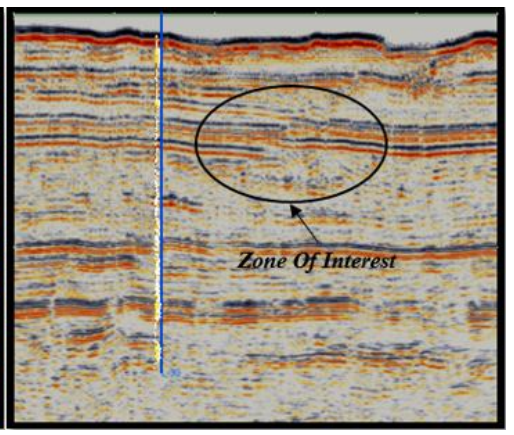

(c)

Gambar 6 (a) Penampang Seismik inline 1284 Tanpa Atribut Energi (b) Penampang Seismik inline 1284 dengan Atribut Energi dan Compuite Gradient Tidak Diaktifkan (c) Penampang Seismik inline 1284 dengan Atribut Energi dan Compuite Gradient Diaktifkan

Penerapan atribut energi dilakukan untuk mengetahui ketidakmenerusan lapisan yang terjadi pada penampang seismik akibat adanya patahan seperti yang terlihat pada Gambar 6 (b). Gambar 6 (b) merupakan hasil analisis atribut energi pada inline 1284 dengan compute gradient nya tidak diaktifkan. Dari Gambar 6 (b) dapat dilihat bahwa resolusi vertikal setelah penerapan 
atribut energi lebih baik dibandingkan dengan Gambar 6 (a). Lingkaran warna hitam merupakan zone of interest yang mengindikasikan adanya diskontinuitas pada lapisan tersebut yang menandakan adanya hidrokarbon. Gambar 6 (c) merupakan hasil analisis atribut energi dengan compute gradient nya diaktifkan. Dari gambar dapat dilihat bahwa indikasi pada zone of interest terlihat semakin jelas seperti yang terlihat pada lingkaran warna hitam.

\subsection{Analisis $S C I$}

Pada penelitian ini dilakukan inversi SCI pada penampang seismik sebagai zona target dengan data seismik post-stack dan data sumur sebagai kontrol. Interpretasi SCI ini dilakukan pada time gate $-28 \mathrm{~ms}$ sampai $+28 \mathrm{~ms}$. Inversi $S C I$ dilakukan untuk mengetahui ketidakmenerusan lapisan yang terjadi pada penampang seismik akibat diskontinuitas yang menggambarkan adanya patahan, adanya lapisan sand dan shale serta nilai $A I$ seperti yang terlihat pada Gambar 7. Gambar 7 menunjukkan bahwa zone of interest (lingkaran warna hitam) lebih dekat dengan sumur L-30 (warna biru) dibandingkan sumur B-41(terdapat di belakang). Pada Gambar 7 juga dapat dilihat bahwa disekitar zone of interest terdapat lapisan shale (warna hijau) dan lapisan sand (warna biru). Gambar 7 menunjukkan bahwa nilai AI pada lapisan tersebut memiliki rentang antara 2,00 x $10^{6} \mathrm{~kg} / \mathrm{m}^{2} \mathrm{~s}$ sampai $5,56 \times 10^{6} \mathrm{~kg} / \mathrm{m}^{2} \mathrm{~s}$, ini menandakan bahwa pada lapisan tersebut memiliki kemungkinan adanya hidrokarbon, karena nilai $A I$ yang rendah pada lapisan batuan terdapat hidrokarbon. Keberadaan hidrokarbon pada lapisan batuan menyebabkan kecepatan gelombang yang merambat pada lapisan batuan tersebut berkurang. Semakin tinggi nilai $A I$ (seperti pada limestone) maka semakin sulit lapisan tersebut untuk dilalui oleh aliran fluida karena struktur lapisan semakin compact, sebaliknya semakin rendah nilai AI (seperti shale dan sand) maka semakin mudah lapisan tersebut untuk dilalui oleh aliran fluida. Berikut merupakan gambar 7 yang menampilkan penampang seismik dan colour bar inline 1284 hasil inversi SCI.

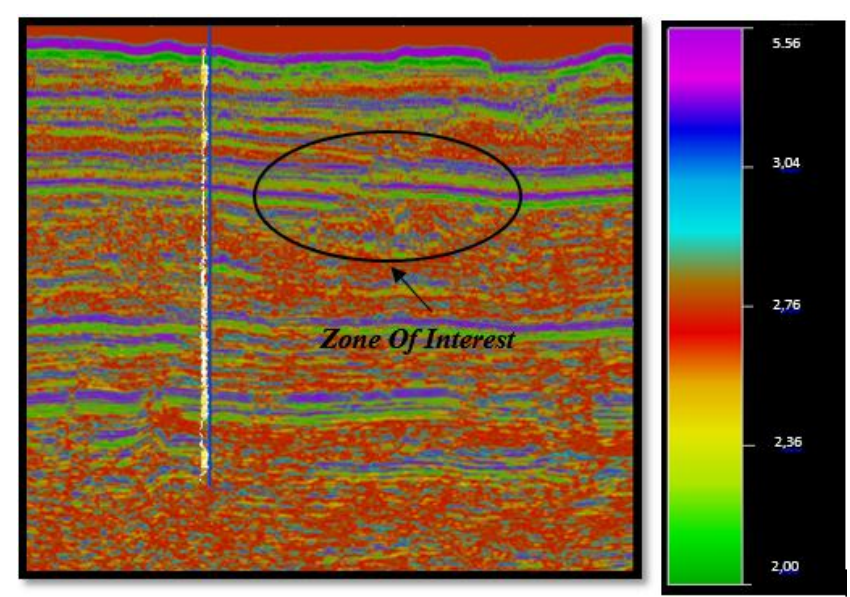

Gambar 7 Penampang AI Sebagai Hasil Inversi Dengan Metode SCI

\section{KESIMPULAN}

Hasil analisis atribut energi menunjukkan bahwa penerapan atribut energi memperjelas keberadaan reservoar hidrokarbon pada suatu penampang seismik. Pemberian atribut energi membantu dalam menentukan zone of interest pada penampang seismik. Dalam penerapan atribut energi, pengaktifan compute gradient memberikan resolusi vertikal yang lebih baik pada penampang seismik dibandingkan atribut energy tanpa compute gradient. Dari analisis inversi $S C I$, diperoleh nilai AI antara 2,00 x $10^{6} \mathrm{~kg} / \mathrm{m}^{2} \mathrm{~s}$ sampai $5,56 \times 10^{6} \mathrm{~kg} / \mathrm{m}^{2} \mathrm{~s}$. Hal ini menunjukkan bahwa pada penampang seismik yang diteliti berkemungkinan diperoleh potensi reservoar hidrokarbon, karena semakin tinggi nilai $A I$ (seperti pada limestone) maka semakin sulit lapisan tersebut untuk dilalui oleh aliran fluida karena struktur lapisan semakin compact, sebaliknya semakin rendah nilai AI (seperti shale dan sand) maka semakin mudah lapisan tersebut untuk dilalui oleh aliran fluida. 


\section{DAFTAR PUSTAKA}

Arifien, H., Inversi Seismik Berbasis Model Untuk Mengkarakterisasi Reservoar Studi Kasus Haurgeulis, Skripsi, FMIPA UI, Jakarta, 2010.

Badley, M.E., Practical Seismic Interpretation, International Human Human Resource Development Co, 1985.

Catra, A.D., Analisa atribut Amplitudo Seismik untuk Karaterisasi Reservoar Lapangan "X" Pada Cekungan Tarakan, Kalimanta Timur, Skripsi, FMIPA UI, Depok, 2010.

Fitri, R., Analisis Atribut Seismik dan Seismic Coloured Inversion (SCI) Pada Lapangan F3 Utara Belanda, Skripsi, Jurusan Fisika Universitas Andalas, Padang, 2016.

Gauthier, D.M. dan Daukoru, E.M., Prediction Of Sub-Seismic Faults And Fractures, American Association Of Petroleum Geologist, Oklahoma, 1993.

Koesoemadinata, R.P., Geologi Minyak dan Gas Bumi Jilid 1, Institut Teknologi Bandung, Bandung, 1980.

Peryoga, A., Karakterisasi Reservoar dengan Menggunakan Metode Inversi Elastic Impedance Studi Kasus Lapangan Penobscot, Skripsi, Kanada, FMIPA UI, Depok, 2011.

Sroor, Mahmoud., Geology \& Geophysics in Oil Exploration. http://www.slideshare.net/FelipeAndrs4/geology-geophysics-in-oil-exploration, 2010 (diakses tanggal 18 Juni 2015).

Sukmono, S., Seismik Inversi Untuk Karakterisasi Reservoar, Geophysical Engineering, Bandung Institute Of Technology, Bandung, 2000.

Tabah , F.R. dan Danusaputro, H., Jurnal Sains \& Matematika (JSM) 18, hal 88-89, 2010.

Whitcombe, D.N. dan Fletcher, J.G., The AIGI Crossplot as an Aid to AVO Analysis and Calibration. Pada: SEG Int'1 Exposition and Annual Meeting. San Antonio, Texas 9-14 September, Texas, 2001. 